might rise onto another New York firm, a subsidiary of Chase Manhattan. If the deal had not been cancelled, one firm would have lost $£ 5,000$ and the other $£ 10,000$.

So what? will be one cynical question. Stockbrokers are forever making huge sums of money by "dealing their books", so why weep when they risk a loss? The simple answer is that it is not their money that they risk, but ours, that invested in the international stock markets by pensions funds, savings institutions and by banks that take deposits from the general public. If Collier had pocketed his $£ 15,000$, the ultimate losers would have been ordinary people. Boesky's $\$ 50$ million ultimately derives from the same source. But $\$ 50$ million is only a tiny fraction of the funds belonging to the public invested in the international financial markets. Is the rest safe?

What worries the Securities and Exchange Commission now is that, in the United States, the huge amount of paper debt obligations called "junk bonds", perhaps as much as $\$ 100,000$ million, which has sustained the recent wave of spectacular takeovers, may be suspect. These securities (if that is the right word) entitle the owner to high interest, but are not secured against assets and not traded on stock exchanges. Holders can get back their capital by appealing to the investment banks that issued the junk bonds, but the fear is that this procedure may have been infected by Boesky get-rich-easy principles; that could spell disaster, given the extent to which savings and loan associations in the United States have traded their clients' cash for junk bonds (which look better on a balance sheet)

So there is a strong case for making outlaws of the insidertraders. How is that to be done? This is the point at which righteous indignation comes a cropper. The case of Collier is straightforward; he acquired his inside knowledge because the firm of which he was a member had agreed to mount a bid for the British engineering company (on behalf of Mr Robert Maxwell, the proprietor of Pergamon Press). To seek to profit personally from this knowledge was a violation of his firm's internal regulations, of the London Stock Exchange's rules and of British government law (hurriedly brought into effect in time to put Collier under pressure). Boesky's is a more complicated case; so far, he has been accused only of using inside information provided by a true insider, Mr Denis Levine, arrested by the Securities and Exchange Commission earlier this year and who has since traded immunity from further prosecution for the repayment of $\$ 1.5$ million and continued cooperation with the commission's inquiries; who, in law, is the real felon, Boesky or Levine?

The truth is even more complicated. Without accepting the arguments of the Chicago economists who say that insider trading is virtuous because it brings reality more speedily into effect and thus make the markets more efficient, it is fair to ask whether stockbrokers who commission studies of industrial sectors, ostensibly for the benefit of clients, should then be allowed to speculate in the stocks concerned. And should the 'analysts' who carry out the research be allowed to speculate on their own accounts, knowing as they must that at least some of their company's clients will believe what they say? When is it improper to act on (and profit from) rumour? Or even to take advantage of special knowledge of the health (or sickness) of publiclyquoted companies gathered in quite different connections, as a journalist, for example?

The righteously indignant will quickly say that there should be no limits to the most simplistic writ. (Simplistic Senator William Proxmire is alarmed at the way in which corporations have been saddled with huge amounts of debt after successfully defending against a takeover bid, but that is another issue for which directors are responsible.) Others will recognize that there is an urgent need for a legal definition of a boundary between right and wrong that will make sense, and will endure. Governments, poor things, will know that the problem is complicated by the international character that the financial markets have now acquired.

\section{Teachers in travail}

Is the proper education of the young too important to be left to teachers?

LiKE motherhood in the old days, the education of the young has become an important social objective, and for good reason; economic survival depends on social or technical innovation, which requires innovative young people. So it is not surprising that governments in the industrialized West should be seeking to improve high-school education. In the United States, the new Democratic Congress has lost little time in saying that it wants the federal government to do more for state-supported school systems. (What will happen to the Gramm-Rudman budget deficit reduction act if the defence budget is not cut?) In Britain, the government is in the last bruising stages of an attempt to trade money (which teachers need) for a promise (which teachers' labour unions are reluctant to concede) that more able teachers will be better rewarded. Everywhere, the simple arithmetic is overlooked.

Here is the arithmetic. Most Western countries send their children to school for 12 or 13 years, in classes that average about 20 students per teacher. In round numbers, the schooling of each child requires roughly two-thirds of a teacher-year. But teachers' professional lives last for about 35 , and are statistically much shorter, which means that for a demographically unchanging population, at least 2 per cent of the population of working age should be schoolteachers. Naturally, governments and the societies they represent require that teachers should have had the benefit of higher education, in which the participation rate in Britain (admittedly one of the worst) is merely 15 per cent. If all those leaving higher education followed professional careers for 35 years (which is far from being true), one seventh of the population would have to be schoolteachers. Allowing for the manpower needs of higher education, one should expect that roughly 20 per cent of college-leavers would be occupied in education. Is it reasonable to expect that those who teach the young will also be among the most talented?

There are three distinct answers to this question. In the United States, where the federal government has, for the past six years, stuck largely to exhortation, but where the quality of high-school education has become a general anxiety, some state governments are making valiant efforts to improve the performance of their schools, while institutions that train teachers are trying to enhance the reputations of those who teach in schools by requiring more from entrants to their courses. These private initiatives have not so far been well-rewarded because people will not pay particularly well-qualified teachers extra, while teachers themselves pretend that discrimination is anathema. In Britain, on the other hand, the government is willing to battle for its conception of a core curriculum and is also pleading for pay-discrimination; it should be known this week or next whether its offer of an extra 17 per cent over 18 months will be accepted on the teachers' terms or will have to be enforced. Only in Japan is there is a workable if unstable solution of the problem: put more than a third of the population through higher education, but then arrange that married women do not work, but stay home and teach their children.

Elsewhere, governments will have to learn to live with solutions far from their ideals. In North America and Western Europe, the chance of persuading the best and brightest of those leaving higher education to teach in schools is small, especially in those fields from which technology springs. Better to be reconciled to that than to keep tilting at a windmill. So the crying need is for a general recognition that schooling is not an end in itself but one of several means to functional adulthood, that the core curriculum should be stripped down so that it is no longer a test of the preternatural ability of gifted students but within the competence of all students and most teachers and that, whatever governments do, the results will not be perfect. 